IJIET, e-ISSN 2548-8430, p-ISSN 2548-8422, Vol. 1, No. 2, July 2017

International Journal of Indonesian Education and Teaching http://e-journal.usd.ac.id/index.php/IJIET

Sanata Dharma University, Yogyakarta, Indonesia

\title{
THE IMPROVEMENT OF TRUTH, JUSTICE, DIVERSITY, AND HUMAN DIGNITY VALUES TROUGH PPKMB PROGRAM ON PHYSICS EDUCATION STUDENTS
}

\author{
Paul Suparno \\ Sanata Dharma University, Yogyakarta \\ paulparno@gmail.com \\ https://doi.org/10.24071/ijiet.2017.010207
}

received 20 April 2017; revised 30 May 2017; accepted 1 July 2017

\begin{abstract}
Sanata Dharma University Physics students are supposed to improve Sanata Dharma main values: truth, justice, diversity, and human dignity. The improvement is done through PPKMB program, a character building program in one semester. This research wants to see whether this program succeeded or not. The research used 42 physics students as sample. The PPKMB program is used as a treatment. The research applied some instruments such as questionnaires, field notes, and student report on their project. Data were analyzed quantitatively and qualitatively. The results show that the truth, justice, and diversity values improved, the human dignity value was not significantly different, and according to the students this program was useful and successful.
\end{abstract}

Keywords: truth, justice, diversity, and human dignity, PPKMB program, physics students.

\section{Introduction}

Beginning the school years 2015-2016, USD (Sanata Dharma University) organized a character building program for new students that is integrated in one academic year. This program is called the PPKMB, consisting of two stages. PPKMB1 is conducted in the first semester and PPKMB2 is done in the second semester. PPKMB1 helps new students to know who they are. They reflect on their strengths, weaknesses, and are helped to accept themselves happily. While the PPKMB2 more helps students to understand and live up to the core spirit of the USD.

The goal of the PPKMB2 program is to help students recognize, explore, and try to live up the USD's four core values, namely: (1) love the truth, (2) fight for Justice, (3) appreciate diversity, and (4) uphold the human dignity (Sarkim, et al., 2016). With this four values, students can eventually develop as a human person who loves the truth, likes to fight for justice, appreciates diversity, and respects human dignity. When students really live up to those values in their lives, they would really be more humanist person.

As a Jesuit University, USD is expected to seek the truth in its entire educational process. In developing science or knowledge, it should also be based 
on the search of truth, honesty, and integrity. Through research, through the excavation of the matter in depth, the value of the truth becomes more approachable. It is expected that students can reach to the real truth i.e. God himself.

In accordance with the characteristics of Jesuit education in the institutions of education (NN., 1987), USD is expected to help each student to be man and woman with and for others. It means that all university members, especially the students, should be supported to be people who appreciate others as a creation of God, be fair to all people and creation. This spirit must clearly manifest in their willingness to live and work with people from diverse backgrounds.

The four core values that are developed in USD will prepare students to actively improve Indonesia as a strong State and nation. Now, Indonesia still has many problems such as corruption, injustice, conflict among citizens, discrimination, and abuse of human dignity. This situation definitely needs people who have the spirit of loving the truth, being fair, appreciating diversity, and upholding human dignity. With this attitude the nation will be more united, and its people will help each other, and respect each other.

In the previous years, the character education program was held for a week outside the campus. But beginning of the year 2016, the PPKMB2 program has been held for one semester, in the regular course hours, i.e. two hours per week. With regular meeting once a week, students can slowly deepen, inculcate, and absorb the character, so that it can better influence students' lives. Because they digest in a long time with the material, hopefully they can learn more smoothly. Moreover, students become more acquainted with their friends closer because every week they have a meeting and collaborate.

This PPKMB2 program is a character building program, generallycontaining two activities. First, students are helped to learn the fourth values: truth, justice, diversity, and human dignity. The process is as follows: (1) The lecturer briefly explains with the help of power point presentation and videos about the four core values, then (2) students in their groups reflect together and express their result in the plenary. Second, students in small groups prepare and decide to build a project. The project is in accordance with the core values that are chosen by the group. In the end, they will reveal the results of the projects in the classroom and upload it on Youtube so that other students can see and benefit from that projects. At the end of the program, students write a reflection on what they have done. This method follows the reflection pedagogy that involves the cycle of experiences, reflection, and action (Duminuco, 2000; Gallagher, Marianne \& Musso, Peter, 2006; NN, 2014; Suparno, 2015).

\section{Loving the Truth}

USD pushes all its members to always love the truth through teachinglearning process and scientific research that will benefit the advancement ofscience, human welfare and environmental sustainability. 'Loving the truth' is also shown through intellectual curiosity and imagination in order to achieve extended scientific expertise. For USD, loving the truth also establishes in the performance of a task correctly (Sarkim, et al., 2016: 9). 
'Loving the truth' means that we continue to initiate the search for truth in the process of education. So, we have to be honest in searching for science and develop it. We need to maintain the integrity in science, such as not cheating, not commiting plagiarism, and not buying grades. Here, scientific honesty needs highesteem both by lecturers and students.

'Loving the truth' is also manifested in the teaching-learning process. In teaching-learning process, students and lecturers have to be honest, have critical thinking, help each other. Professors and students have to do their job properly and not to cheat or manipulate in carrying out their duties.

'Loving the truth' is also shown in scientific research. In the situation where many people are dishonest in conducting research, in writing thesis, we are invited to remain honest. Professors and students have to be aware of not commiting fraud, cheating, and plagiarism. We have to appreciate the work of others. Students from the beginning year are invited to peruse the work of others and honestly cite their names. Cultural copy paste from the internet needs to be scrutinized so that we really learn to be honest in this regard. Also, attention should be given to 'free riders' or the students who did not join the group workbut his name is listed in the report of the group. Sometimes students do not dare toreport here.

'Loving the truth' is the essence of the spirit of USD as a Jesuit University. Ignatian Spirituality which is used as a foundation in the life of the University, clearly says that we are invited to always seek the truth, even the highest truth of God himself (Byron, 2008:16).

Fighting for Justice

The second core value of USD is justice. The fight for Justice is a core value for the creation of a society that is dignified and equal in front of the creator. The fight for justice is realized through alignments to those who suffered injustice, especially the small, weak, poor, disabled and retired. The strong view is based on a comprehensive analysis that can be scientifically justified and in accordance with the demands of social morals.

Thomas Aquinas stated that justice is one of the core moral virtues that becomes the requirement for people who want to live in prosperity. Other virtue is wisdom, inner firmness, and simplicity. Justice is a virtue that drives people to intend and act justly on their neighbour, give what becomes their rights (Sarkim, et al., 2016: 10).

An important element of justice is orientation for others, rights and equality. The attitude of the fairness happens when people give to others the rights that are attached to it. The right is not supernatural. This is obtained because the man is a creation of sensible prudence. The right becomes the basis of the concept of human rights.

Suseno $(1986,1987)$ distinguishes four kinds of justice such as: commutative, distributive, legal, and social justice. Commutative justice is a justice because of an agreement. Man or woman is considered fair if he/she fulfills his/her promises on others. If he/she is promised to give the book A, he/she really gives the book A. Distributive justice is a justice of division or dividing equally. In this case a person is considered fair when he shares the flat 
into the rights of others. For example, Mr. A is called fair when he divides his inheritance equally to his children. Legal justice is a justice according the law. Everyone gets the same treatment before the law. There is no difference between ordinary residents and government officials. If they steal from others, they need to be treated the same in the face of the law.

Besides those three justices, Suseno (1986) explains the existence of social justice. Social justice gives the situation, so that the three justices above can be implemented, so that everyone can exercise his right. If the basic situation does not exist, it will be difficult to carry out the right of each people. For example, people who do not know education, it would be difficult to prosecute him/her legal rights at the institute for justice. Then the government should strive to letany citizen experience education so that he/she can read and is able to demand her/his rights.

In general, social justice is a justice that must be executed by the public or the government. The government should have to regulate the use of the propertyof the state in the interest of the public. The state should safeguard social justice for every citizen, so that he/she can obtain justice.

If we look at our community situation, we can see some forms of injustice that happen such as: discrimination of gender, race, tribe, religion, beliefs, and ability. For example, women are prohibited to go out from her home after $9 \mathrm{pm}$, while men do allow. Some discriminations because of religion often occur, so the society situation is not peaceful yet. Employee recruitment is still rife with discrimination.

As a Jesuit University, USD is indeed expected to develop an attitude of fairness and realize justice among the students. Issues and concerns of injustice need to be addressed in the curriculum and discussed in seminars, and students aretrained to act fairly and get involved in the question of defending justice in the communities (NN., 1987). The sense of being fair also is related to issues of fairness with the surrounding environment and the universe. Thus, the question of caring for the environment is also becoming a question of attitude of justice (cf. Curing a sick world, 2012). The entire USD members, both professors, students, employees and officials, should develop an attitude of fairness. The important thing is awareness and sensitivity on the small, weak, poor, and retired. This attitude should also appear in our actions out of the campus.

\section{Valuing Diversity}

Indonesia consists of a wide range of tribal, racial, religious, social, cultural backgrounds. USD also consists of a wide range of people, tribe, race, religion, societies and cultures. They are multicultural. This nation can only progress forward if the people from diverse backgrounds want to cooperate and work together. They should be willing to cooperate and live together despite their differences. To prepare for it, USD should help their members to accept and appreciate differences. Then, the attitude of valuing diversity becomes very important in USD. The attitude of valuing diversity and happily living with different people should be trained and developed.

The attitude of valuing diversity is the basis for improving the quality of human relationships for the sake of the realization of an open and democratic 
society. Valuing diversity is manifested through the recognition of the diverse culture, wealth, talent, the uniqueness of each person. It is also manifested in the willingness to cultivate cooperation cross science, so an intellectual, productive, creative and critical communication will be created (Sarkim, et al., 2016: 12).

Valuing diversity means we must courageously accept and be excited by the existence of differences between us. We accept diversity and are grateful for it.We appreciate the idiosyncrasies of each of them. In this spirit of PPKMB2 students learn increasingly and recognize the specificity and their differences, and accept others as a brother. Through doing project in a group whose members are chosen differently (multicultural), students learn to accept other friends and appreciate diversity.

\section{Upholding the Human Dignity}

The fourth core value of USD is upholding the human dignity. People are God's creation with value and dignity. The value of humanity cannot be debased by anyone. We all have to develop this. The human dignity value will be seen in a person who loves the truth, fights for justice, and appreciates diversity. As students, we should be grateful because we are more educated than most of the Indonesia society. As scholars we have an obligation to embody the society to be more dignified (Sarkim, et al., 2016).

There are many ways to value human dignity, namely: respect every human person; use our talents to help others; tune in to the needs of others; be useful for the progress of others; be responsible for the progress of society; maintain the Earth in order to sustain human life; present and support a dignified society; cultivate the heart and desire blazing to manifest our dreams for a better society changes (Sarkim, et al., 2016).

As a Jesuit University, USD is expected to help and develop their students to be increasingly appreciative of the human person. They become aware that we should value anyone, as any man is of high value before God. All forms of harassment and bullying people for personal interests need to be prevented and eliminated. The main concern needs to be directed at those who are weak, poor, and helpless.

The purpose of this research is to know: (1) whether after following PPKMB2 program, the USD physics education students experience the improvement of their spirit to love the truth, to fight for justice, to appreciate diversity, and to uphold human dignity; and (2) whether the PPKMB2 program is perceived by the students as useful and successful.

\section{Method}

This research is quantitative and qualitative research. Quantitative research is used to see the students' improvement of the four core values of USD: (1) love the truth, (2) fight for Justice, (3) appreciate diversity, and (4) uphold the human dignity. Pretest is conducted before students doing the PPKMB2 program and posttest is done after they finishing PPKMB2 program. By comparing the values of the pretest and the posttest, it can be known whether students improve those core values. Qualitative data are taken from the students' report of their projects; 
students and lecturers' field notes, and students' reflection. The qualitative research to understand the usefulness and benefits of this program for students.

The sample of this research was 42 second-semester students of physics education. The total number of students was 45 , but three students did either the pretest only or posttest only, so their data cannot be used in the analysis.

This research was held for one semester, from February to May 2016. This research was done in USD campus and outside campus.

PPKMB2 program is used as a treatment in this study. Students conducted this program for one semester. They learned, discussed, did presentation, and reflected on the four core values. After that, they planned a project in a group of six students that wanted to be conducted over the next few weeks off-campus or oncampus. Projects were chosen by the group according to the value that they wanted to be accentuated. Each group presented the results of the projects to the class. In the end, students did reflection and evaluation on the program.

The instruments used in the study are a pretest (pre-questionnaire) and posttest (post questionnaire). The test consists of 100 items, divided in four groups: 25 items about the value of love the truth, 25 items about the fight for Justice, 25 items about valuing diversity, and 25 items about upholding human dignity. Each value is seen from the side of knowledge (cognitive), affection (attitude), and action (implementation).

In addition to the above questionnaires, researcher also uses students reports about their project; students 'evalution and reflection on this program; and fieldnotes that primarily contain students mood, attitudes, and gestures during the program.

Students' answers in the test are scored in accordance with rules such as: 4 (very good), 3 (good), 2 (less good), 1 (not good). Then they are analyzed using ttest for dependent groups between pretest and posttest score value for the four core values. By using the SPSS program it can be seen whether its increase is significant or not. The data from students' evaluation and reflection and their report on their project are analyzed qualitatively.

\section{Findings and Discussion}

The number of students who initially participated in this character building were 45 students, but ony 42 students finished the program, so in the analysis we used only the data from 42 students. Students were divided into seven groups witheach group consisting of six people. There are seven projects with different valuessuch as table 1.

Table 1. Project Name

\begin{tabular}{llll}
\hline No. & \multicolumn{1}{c}{ Project Name } & Core Value & \multicolumn{1}{c}{ Places } \\
\hline 1 & $\begin{array}{l}\text { Making video about Enhancing } \\
\text { the culture of courtesy }\end{array}$ & human dignity & $\begin{array}{l}\text { Campus and off- } \\
\text { campus }\end{array}$ \\
\hline 2 & $\begin{array}{l}\text { Making video about "Live in } \\
\text { an apartement which is less } \\
\text { good" }\end{array}$ & human dignity & $\begin{array}{l}\text { apartement near } \\
\text { campus }\end{array}$ \\
\hline 3 & Teaching street children about & human dignity & outside campus \\
\hline
\end{tabular}




\begin{tabular}{llll}
\hline & $\begin{array}{l}\text { basic mathematics and English } \\
\text { language }\end{array}$ & and truth & \\
\hline 4 & $\begin{array}{l}\text { Visit and play with the double } \\
\text { disabled children }\end{array}$ & $\begin{array}{l}\text { human dignity } \\
\text { \& diversity }\end{array}$ & disable houses \\
\hline 5 & $\begin{array}{l}\text { Live in and help a peasant } \\
\text { family }\end{array}$ & $\begin{array}{l}\text { human dignity } \\
\text { \& diversity }\end{array}$ & peasant home \\
\hline 6 & Clean up trash on the beach & justice & Wonosari south beach \\
\hline 7 & $\begin{array}{l}\text { Water in Jogya Bay (research } \\
\text { community) }\end{array}$ & justice & villages near Jogya \\
bay
\end{tabular}

All the groups completed their projects and collected project reports. The majority stated that the project was successful, they were happy, and excited about the project. Two groups already uploaded videos on YouTube. The uploaded videos can be viewed by other people. They also wrote down their reflections and evaluations about their project, which can be used as additional data in this study.

\section{Results of pretest and posttest scores}

The following table (table 2) presents the result of students pretest and posttest about the four core values i.e. love the truth, fight for justice, appreciate diversity, and uphold human dignity. The score is the average value of each core values.

Table 2. The results of pretest and posttest: average of each value

\begin{tabular}{clcccccccc}
\hline \multicolumn{9}{c}{ Prestest } & \multicolumn{7}{c}{ Posttest } \\
\hline No & Value & cognitive & affection & action & Total & cognitive & affection & action & Total \\
\hline 1 & Truth & 25.79 & 28.55 & 49.05 & 103.38 & 26.90 & 29.79 & 51.14 & 107.83 \\
\hline 2 & Justice & 36.55 & 24.12 & 43.57 & 104.24 & 37.52 & 25.26 & 45.95 & 108.74 \\
\hline 3 & Diversity & 32.45 & 30.45 & 48.00 & 110.90 & 33.40 & 31.81 & 49.45 & 114.67 \\
\hline 4 & $\begin{array}{l}\text { Human } \\
\text { dignity }\end{array}$ & 33.12 & 36.83 & 43.36 & 113.31 & 33.43 & 37.17 & 44.45 & 115.05 \\
\hline
\end{tabular}

From table 2, it appears that all posttest average is higher than that of the pretest. It indicates that the students increase their character on 4 USD core values. According to the statistical analysis, the result can be seen in table 3 .

Table 3. Statistical Test results using t-test

\begin{tabular}{lccccc}
\hline \multicolumn{1}{c}{ Value } & $\begin{array}{c}\text { pretest } \\
\text { Mean }\end{array}$ & $\begin{array}{c}\text { posttest } \\
\text { mean }\end{array}$ & t-value & significant & Notes \\
\hline 1. Truth & 103.38 & 107.83 & -2.504 & 0.016 & significant \\
\hline 2. Justice & 104.24 & 108.74 & -2.683 & 0.010 & significant \\
\hline 3. Diversity & 110.90 & 114.67 & -2.895 & 0.006 & significant \\
\hline $\begin{array}{l}\text { 4. Human } \\
\text { dignity }\end{array}$ & 113.31 & 115.05 & -1.704 & 0.096 & $\begin{array}{l}\text { not } \\
\text { significant }\end{array}$ \\
\hline
\end{tabular}

From table 3, it seems that the value of truth, justice, and the diversity are statistically significant which means that students improve their values. While the 
value of the human dignity is not significant. It means that in this value, students did not improve, eventhough the posttest mean is higher that the pretest mean.

\section{Students' reflection and evaluation about PPKMB2 Program}

At the end of the program, students did a reflection by writing down what they experienced during the entire program. Students also wrote a project report about what they did with their project and how they felt and satisfied with their projects. The results are as follows:

\section{The success of the project}

Most students felt satisfied, excited, and happy with the project. They were happy because the projects were successful $(90 \%, 85 \%)$; their group was solid, they helped each other and had good cooperation. They learned to appreciate one another, they became closer with their friends. They were also happy because they could teach other kids, were able to help the kids happy, and they were close to children. They could learn from friends who were there in the locations and also love them. They can meet directly with victims of injustice and felt touched.

Whereas some were not satisfied because they felt that an important issue (Jogya Bay) was not discussed deeply. Several students were not satisfied because of insufficient time to complete their tasks, the video was insufficient, and some felt that they were less friendly.

\section{The impact for others}

Most students felt that they were able to help other people. Their project helped some children to grow. They also learned how to listen to other people who had dificulty. They learned how to become the shoulders to cry on.

\section{Usability for the student's own}

Almost all of the students stated that the PPKMB2 program and especially the project was very useful for their lives. Some state as follows:

- Getting to know other friends, appreciating, and cooperating with them, and not discriminating friends;

- Becoming more aware to care for others, the environment, and justice, to not harm others;

- Increasingly being aware of the culture of courtesy, be aware of the bad behaviors, know better etiquette among friends and others;

- Establishing a good cooperation with friends, more familiar, closer, solid, and being open to each other;

- Becoming more thankful for their lives that were given by God, because of the help of parents;

- Learning how to live simply, not extravagant, appreciating the food, knowing how to struggle in daily life;

- Becoming more social, more helpful, fighting for Justice, equl chance for learning with nature and their fellows, mutual caring, and sharing.

\section{The influence to the future life}

Based on this project experience, in the future students want to do a better life and make more action, such as honor and respect to their fellows; help afellow in need, do a charity program and social activities for those who are not able to; they want to avoid discrimination to choose friends, want to respect human dignity, and be fair with others. 
Students also want to be more caring and sensitive on their environment, eliminate bad habits, and be polite. They also want to increasingly develop their competence in reflecting on the core values. They want to learn responsibility, discipline, and involve in organizations.

\section{The increase of the love of truth value}

The increased spirit of students in loving the truth can be seen from the comparison of the level of love the truth on pretest and posttest after students did the PPKMB2 program. From table 3 it can be seen that pretest average is $\mathbf{1 0 3 . 3 8}$ and the posttest average is $\mathbf{1 0 7 . 8 3}$. The value $\boldsymbol{t}=\mathbf{- 2 . 5 0 4}$, and $\boldsymbol{p}=\mathbf{0 . 0 1 6}$. Because $\boldsymbol{p}$ is smaller than the $\boldsymbol{\alpha}=\mathbf{0 . 0 5}$, then it is significant. That means the value of the posttest is better than on the pretest. In other words, students improve their love of truth value.

It can be inferred that the spirit of students to love truth is rising. This concerns both in the understanding, affection, and action. Thus it can be said that the PPKMB2 program improves students spirit in the love of the truth. With this result clearly PPKMB2 program supports students to realize, deepen, train, and develop the values of love of the truth. The values thrive in the educational process in the next semester.

It is interesting that only one grup chose this value for their project. The group teaches mathematics and English language to street children. It seems that for the students, the value of honesty or truth means more on integrity in academicfield, such as not cheating, not doing plagiarism; but they do not yet realize that the value of truth concerns the entire human life including in building friendship with others openly and honestly.

\section{Enhancement of students fight for Justice}

Enhancement of students' value of fighting for Justice can be seen from the comparison of students' score of 'fight for justice' before and after doing the PPKMB2 program. In table 3, it appears that most students experience increased passion to fight for justice. This can be seen from the value $\boldsymbol{t}=\mathbf{- 2 . 6 8 3}$ with $\boldsymbol{p}=$ 0.010. From these results, it can be said that the program is able to help students develop their understanding, affection, and actions to fight for Justice in their lives.

There are two groups who explicitly chose to develop the core value of 'fight for justice' both on campus and in the community. The first project is researching the influence of Jogya Bay project on the shortage of water in the surrounding communities. From this project, the students are aware that development should pay attention to justice for the surrounding communities. The second project is cleaning up trash on the beach. In this project, the students realize that we should also be fair with nature and the environment.

The attitude of fighting for Justice is also experienced by students in their cooperation groups. Most of the group said that they learned how to divide the work and the burden equitably among friends.

\section{The increase in the value of appreciating diversity}

The increase in the value of appreciating diversity can be seen by comparing the pretest and posttest scores of the value of diversity. From table 3, it can be seen that the students improve their value of appreciating diversity. This can be 
seen from $\boldsymbol{t}=\mathbf{- 2 . 8 9 5}$ with $\boldsymbol{p}=\mathbf{0 . 0 0 6}$, and $\boldsymbol{\alpha}=\mathbf{0 . 0 5}$. It is significant. So, it can be concluded that the students experienced an increase in the value of appreciating diversity.

From students' project reports, most students became more able to accept and cooperate with their friends of different cultures, religions, and ethnicities. They said that they became more solid and could receive diversity among them. They regard their friends as brothers. The students from outside Java felt excited because they were accepted at the home of a Javanese family nicely and were considered as their own sons without regarding their different religious, ethnic, cultural backgrounds. That experience makes the students more aware of the importance of valuing diversity in this life.

The experience of living with different people in the project spurred students to develop the spirit of valuing diversity in their life on campus. Some students make intention for not discriminating their friends in class because all their friends can become their real friend.

In fact the value of appreciating diversity becomes even more accepted if people experience in their lives, the acceptance and good relationships with different people. This experience is more helpful for students to appreciate other people. The attitude of valuing diversity is not more on knowledge, but more on affection and action, so it needs experiences. Thus the project of living together and working together need to be more emphasized in education.

\section{The increase of upholding human dignity value}

The increase in the value of upholding human dignity after doing the PPKMB2 program can be seen by comparing the value of pretest and posttest scores of students. In Table 3, it can be seen that the mean of posttest scores is higher than pretest scores. The value of $\boldsymbol{p}=\mathbf{0 . 0 5 2}$ and it is higher than $\boldsymbol{\alpha}=\mathbf{0 . 0 5}$. So, it is non significant. From here it can be concluded that the value of upholdinghuman dignity does not increase, except in terms of the action.

From the students' reflection on their project, mostly they appreciate human dignity, they increasingly appreciate the dignity of human beings. They are aware that every human being is precious and must be appreciated. The experience of students helping disabled children, helping street children, learning to be polite to friends and others, shows that they appreciate the value human beings.

\section{The success and usefulness of the PPKMB2 program}

From the results of students' reflection and evaluation, most of students said that the program was successful and useful for their lives. They even planned to continually develop these values after the completion of this progam. The students got excited, thrilled, and proud because this program worked well. What they have planned could indeed be executed.

One of the major use of this progam is that their brotherhood became increasingly stronger, and they came to the awareness for not discriminating against their friends in class, because anyone can be a friend. They do not marginalize among friends because of race, tribe, religion, intelligence. Instead, everyone had the same human value.

From this reflection, they wanted to let this program be sustained so that students are increasingly becoming one and really appreciate the value of a human 
being. This award will be a cornerstone of us as nations, and to uphold the unity of the nation. From this side of the Indonesian nation building, this program helps students to appreciate others and to cooperate with others. From this result, it can be seen that the PPKMB2 program that used pedagogy reflection method really improve students' characters.

\section{Conclusions}

From this study, it can be inferred that several points are related to the goals of this research. First, after they experienced the PPKMB2 program, the secondsemester physics education students of 2015/2016 improve their passion for the love of truth, the spirit to fight for Justice, their passion to appreciate diversity, and their spirit to uphold human dignity. Second, students thought that this PPKMB2 program was successful and very useful for their lives. They said that their program was successful because they could finish their program well and what they had prepared could be accomplished. The program is useful because they improved their core values such as to love the truth, to fight for justice, to value diversity, and to uphold human dignity. They become brothers amongfriends and appreciate other people.

From the findings, there are some suggestions that may be emphasized. First, this program can be continued because it is very useful for students. Second, after the project, students should be given the opportunity to experience field experience cognitively so their understanding is also evolving in tune with their field experience. Third, time setting may be needed so that their programs can be completed on time. Fourth, it is better to use a project in building character compared to lecturing.

\section{References}

Byron, W. (2008). Sharing the Ignatian Spirits with friends and colleagues. Chicago: Loyola Press.

Duminuco. (Ed.). (2000). The Jesuit ratio studiorum: 400 th anniversary perspectives. New York: Fordham University Press.

Gallagher, M., \& Susso, P. (2006). Ignatian pedagogical paradigm synopsis. JSEA. March 2006.

Suseno, F. (1986). Kuasa dan moral. Jakarta: PT Gramedia.

Suseno, F. (1987). Etika dasar. Yogyakarta: Kanisius.

NN. (1987). Ciri-ciri khas pendidikan pada lembaga Pendidikan Jesuit. Yogyakarta: Kanisius.

NN. (2014). Ignatian pedagogy: An abridged version. London: Jesuit Institute.

Sarkim, dkk. (2016). Pendampingan pengambangan kepribadian dan metode belajar 2 (PPKMB2). Yogyakarta: Universitas Sanata Dharma.

Suparno, P. (2015). Pembelajaran di perguruan tinggi bergaya PPR. Yogyakarta: Universitas Sanata Dharma. 